\title{
Effects of strontium ranilate and Hypericum perforatum extract on experimental colitis model in rats
}

\section{Stronsiyum ranilat ve Hypericum Perforatum eksraktının ratlarda deneysel kolit modeli üzerine etkileri}

\begin{abstract}
Atilla Kurt ${ }^{1}$ Cumhuriyet University, Faculty of Medicine, Department of General Surgery,Sivas Sinan Soylu ${ }^{1}$ Cumhuriyet University, Faculty of Medicine, Department of General Surgery, Sivas Zeynep Deniz Şahin İnal ${ }^{2}$ Cumhuriyet University, Faculty of Medicine, Department of Histology and Embriology, Sivas

Ömer Topçu ${ }^{1}$ Cumhuriyet University, Faculty of Medicine, Department of General Surgery, Sivas Mustafa Atabey ${ }^{1}$ Cumhuriyet University, Faculty of Medicine, Department of Generall Surgery, Sivas
\end{abstract}

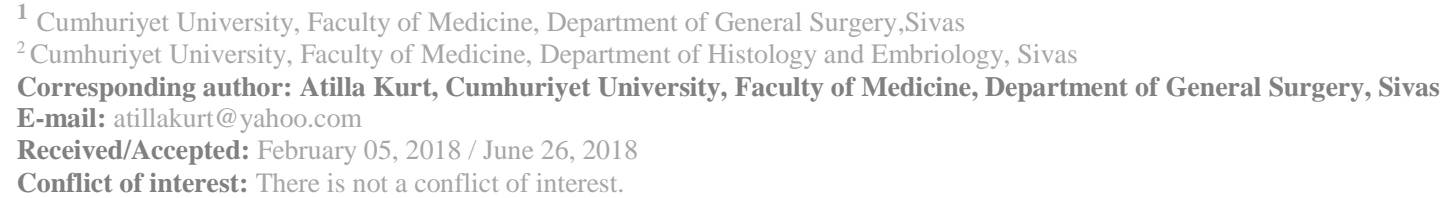

\section{SUMMARY}

Objective: In this study, we aimed to compare the healing effect of strontium ranilate(SR) and hypericum perfaratum (HPE) with the healing effect of prednisolone used in the treatment of experimental colit in rats.

Method: 30 wistar albino rats were used in the study. Rats were randomly assigned to 5 consecutive groups consisting of 5 rats. Group 1, healthy rats, group 2 colitis but untreated rats. The rats in groups 3, 4, and 5 had colitis and received $160 \mathrm{mg} / \mathrm{kg} \mathrm{SR}, 1 \mathrm{mg} / \mathrm{kg}$ prednisolone and HP extracts containing $0.3 \%$ hiperisine (250 uq / $300 \mathrm{mg}$ ) by oral gavage, respectively for seven days. At the end of the seventh day, the colons of the rats were removed and histopathological examination was performed.

Results: The histopathological results of the HPE group were statistically worst including the control group. It was observed that the best results in the treatment groups were SR group followed by prednisolone group, respectively. $(\mathrm{P}<0.05)$

Conclusions: This study concluded that SR was at least as effective as prednisolone in colitis treatment, but HPE exacerbate colitis-induced inflammation when received by orally.

Keywords: Strontium, Hypericum perforatum, colit

\section{ÖZET}

Amaç: Bu çalışmada stronsiyum ranilatın (SR), Hypericum perforatum (HP) ekstresinin deneysel kolit oluşturulan ratlarda iyileştirici etkisini tedavide kullanılan prednizolonun iyileştirici etkisiyle karşılaştırmak istedik.

Yöntem: Çalışmada 30 adet Wistar albino rat kullanıldı. Ratlar 6'şarlı 5 gruba rastgele ayrıldı. Grup1 sağlıklı kolit oluşturulmamış ratlar, Grup 2 kolit oluşturulmuş fakat tedavi verilmemiş ratlar, Grup 3 kolit oluşturulup 160mg/kg SR verilen ratlar, Grup 4 kolit oluşturulup prednizolon (prednol-L Mustafa Nevzat $\left.{ }^{\circledR}\right)(1 \mathrm{mg} / \mathrm{kg})$ verilenler, grup 5 kolit oluşturulup $0.3 \%$ hiperisin içeren HP ekstresi $(250 \mu \mathrm{g} / 300 \mathrm{mg})$ verilen ratlar olarak gruplar oluşturuldu. Bütün tedavi gruplarına yedi gün boyunca oral gavaj yöntemi ile tedavileri uygulandı. Yedinci gün sonunda ratların kolonları çıkarılarak histopatolojik incelemeye alınd1. 
Bulgular: HPE kullanılan grupta histopatolojik sonuçların istatiksel olarak kontrol grubu da dahil olmak üzere en kötü olduğu görüldü. Tedavi gruplarında en iyi sonuçların SR grubu olduğu bunu sırasıyla prednizolon'un takip ettiği görüldü $(\mathrm{p}<0.05)$.

Sonuç: Bu çalışmada kolit tedavisinde SR'ın en az prednizolon kadar etkin olduğu, ancak HPE' larının oral olarak kullanıldığında kolitte oluşan inflamasyonu arttırdığı sonucuna varıldı.

Anahtar sözcükler: Strontium, hypericum perforatum, colit

\section{INTRODUCTION}

Inflammatory Bowel Disease (IBD) is a term used to describe ulcerative colitis and Crohn's disease. The etiology of these diseases are not fully known. They are interrelated because of common clinical symptoms and similar histopathologic apperance. One of the organs commonly affected by two diseases is the colon. The pathogenesis of these diseases is not fully understood. Because of the side effects of the medicines used in the treatment, there is a need to try drugs with fewer side effects.

In genetically predisposed individuals, it is thought that an abnormal immun-response may occur to the intestinal flora. Tumor Necrosis Factor(TNFalpha), which is a proinflammatory cytokine in IBD, is known to play an important role in pathogenesis (1-3). It has been shown in adults and pediatric patients that TNF-alpha suppression decreases clinical symptoms in the treatment of patients $(4,5)$. In patients with active colitis, NF- $\kappa \mathrm{B}$ activity was demonstrated in mucosal biopsies of patients with active colitis (6). Currently, steroids used in therapy improve clinical symptoms by reducing NF- $\mathrm{kB}$ activity(6).

SR is a compound that has been shown to have a positive effect on inflammation. In studies performed, SR has been shown to be effective in allergic rhinitis and ulcerative colitis (7), and it is also used in the treatment of osteoporosis and pain associated with bone metastasis $(8,9)$. Recently it has been shown that strontium inhibits inflammatory mediators by blocking TNF-alpha (10-11).

HP is used in the cold, biliary disorders and bladder irritation, neuralgia, migraine pain, sedation, sciatica and various ulcers, dyspepsia treatment, anti-spasmodically and externally, wound healing and as an anti-septic (12-13). It's antiinflammatory effect is known (14). In this study, we wanted to compare the curing effect of SR, HP extract and prednisolone on experimental colitisinduced rats.

\section{MATERIAL AND METHODS}

\section{Ethics}

Ethical approval was obtained by the Animal Ethics Committee of Cumhuriyet University on 12.4.2017 with 65202830-050.04.04-51 number.

\section{Rats}

30 wistar albino rats were included in the study. Standard laboratory conditions. (12 hours day / night, $25+-3$ C, 45-64\% humidity) and free access to the standard rat diet and water. Experiments were conducted between 08:00 and 12:00 in the daytime to protect against circadian effects.

\section{Formation of colitis}

Experimental colitis was formed by the method described by Mousavizadeh et al. (15). Under anesthesia, 4\% acetic acid solution in $2 \mathrm{ml}$ of ethanol was transrectally applied with a pediatric soft catheter $(2,7 \mathrm{~mm})$. After acetic acid administration, ratswere holed horizontally for 2 minutes to prevent acetic acid leakage.The rats were randomly divided into 5 groups consisting of 6 rats. Group 1, healthy rats, group 2 colitis but untreated rats. The rats in groups 3, 4, and 5 had colitis and received $160 \mathrm{mg} / \mathrm{kg} \mathrm{SR}, 1 \mathrm{mg} / \mathrm{kg}$ prednisolone (prednol-L Mustafa Nevzat $\AA$ ) and HP extracts containing $0.3 \%$ hiperisine (250 uq / $300 \mathrm{mg}$ ) by oral gavage, respectively for seven days.

\section{Histopathologic Evaluation}

Seven days after colitis formation, the rats were sacrificed by cervical subluxation. the colon segments were removed.. The colons were opened longitudinally and washed with saline. $6 \mathrm{~mm}$ serial sections were taken and fixed in $10 \%$ neutral formalin for 24-48 hours. buried in paraffin blocks. $5 \mu \mathrm{m}$ sections were prepared and stained with hemotoxylin-eosin. All sections (four sections for each tissue) were examined. sections with artefacts due to dyeing were not evaluated. After the staining was completed, all preparations were viewed on a light microscope (Olympus BX-51 Tokyo, Japan) for the presence of ischemic damage on the colons. Histopathological evaluation was performed by a single pathologist who was blinded to the groups. 
Histopathological results were evaluated by the scoring system determined by Chiu (16), (Table 1).

Table 1. Histopathological improvement scores in the study groups

\begin{tabular}{|llccccc|}
\hline & Groups & Min & Max & Median & $\begin{array}{c}\text { Standard } \\
\text { deviation }\end{array}$ & p \\
& Sham & 0 & 1 & 0,17 & 0,41 & $<0,001$ \\
& Control & 4 & 5 & 4,17 & 0,41 & \\
Histopathology & HP & 4 & 5 & 4,83 & 0,41 & \\
& Prednizolon & 2 & 3 & 2,33 & 0,52 & \\
& SR & 1 & 2 & 1,33 & 0,52 & \\
\hline
\end{tabular}

\section{Statistical Analysis}

The data were analyzed with the SPSS 15.0 package software. Evaluation according to groups; Kruskal-Wallis $\mathrm{H}$ test was used in multiple groups (calculation of the difference of more than one group). Mann-Whitney $\mathrm{U}$ test was used to investigate which groups were different when multiple comparisons were found.

\section{RESULTS}

When all groups with colitis were examined, the results were statistically worst in the group using HPE, including the control group. It was observed that the best results in the treatment groups were the SR group followed by the prednisolone group respectively. ( $\mathrm{p}<0.05$ ) Table 1 shows the histopathological tissue scorings. Graphs 1 demonstrates the histopathological changes in experimental animals.

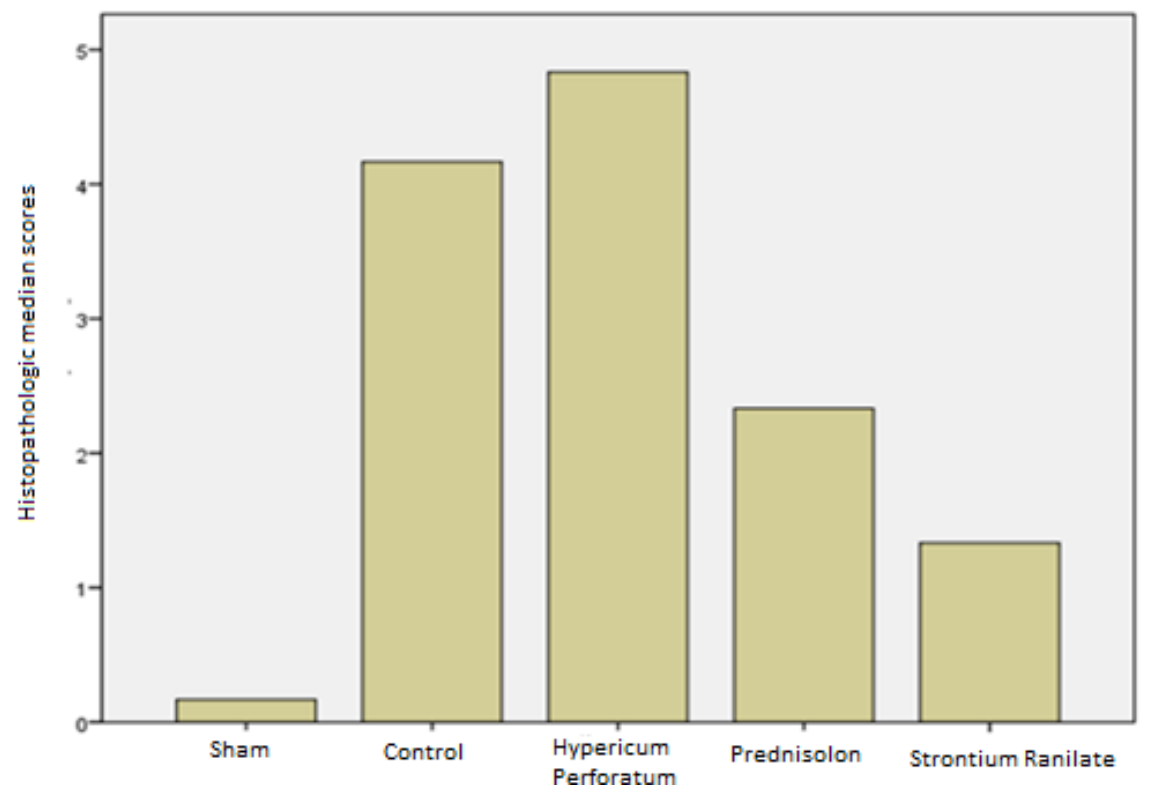

Graph 1. Histopathological Score Averages According to Study Groups 


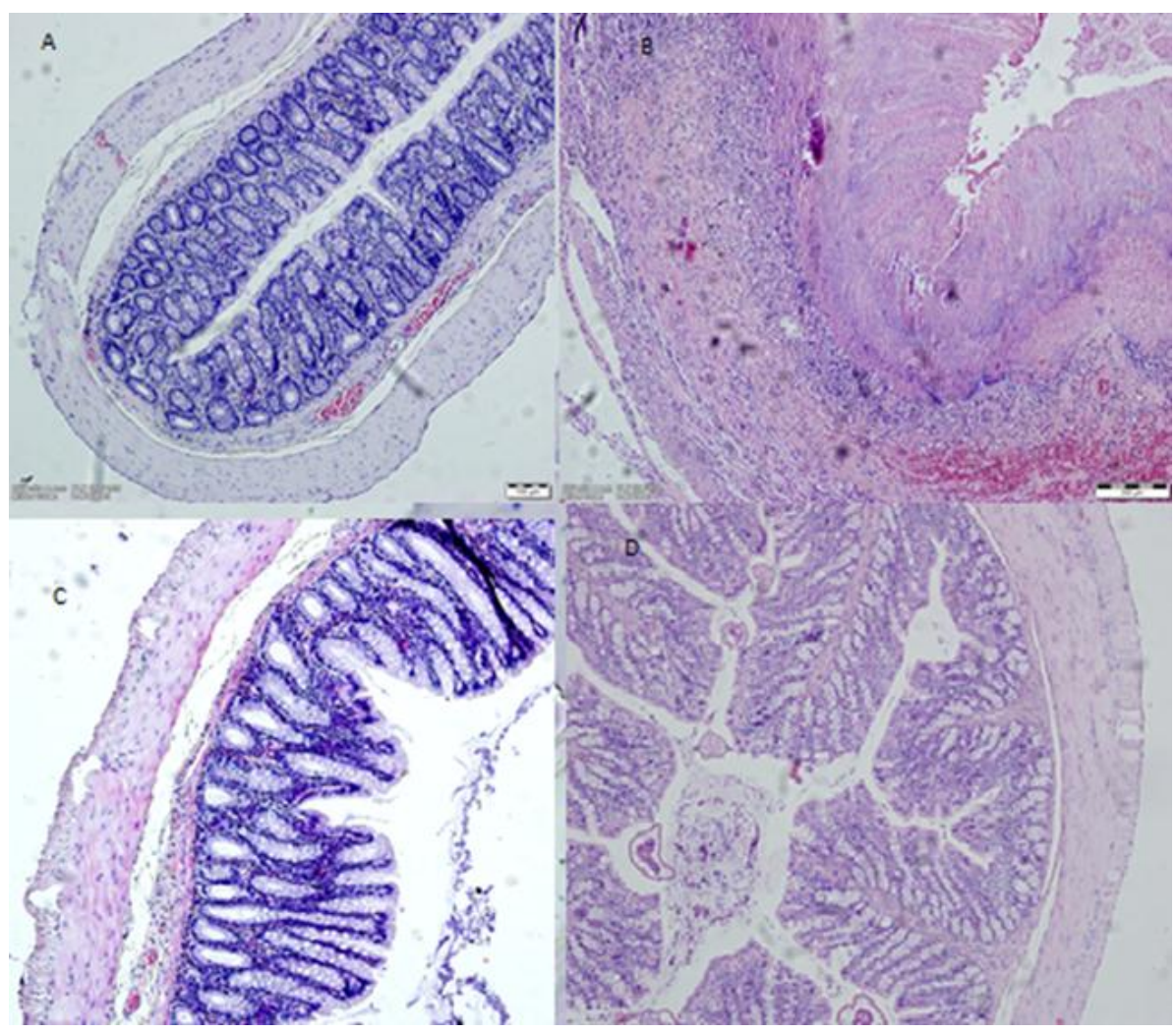

Picture-1: Histopatologic apperance of the Tissues in 10x

A: Control group: The tunica mucosa is a lamina propria located under the epithelium and epithelium that form the basal lamina propria, as it should be. Tunica submucosa and muscularis layers were also observed in normal form.

B: Hypericum Perforatum: Tunica mucosa, submucosa and muskularis layers are completely deteriorated in structural integrity.

C: Prednisolon: Regularly arranged layers are observed. it is observed that the epithelium is spilled locally, though not as much as in the HP group. It can be stated that the lamina propria continues in its normal course. Although the tunica submucosa is regularly steady, dilate blood vessels are observed in places. Tunica muskularis is in normal course.

D:Strontium: All layers show regular navigation. It has been determined that although the epithelium is sparse in the tunica mucosa at minimal level, it is the source of the preparation. 


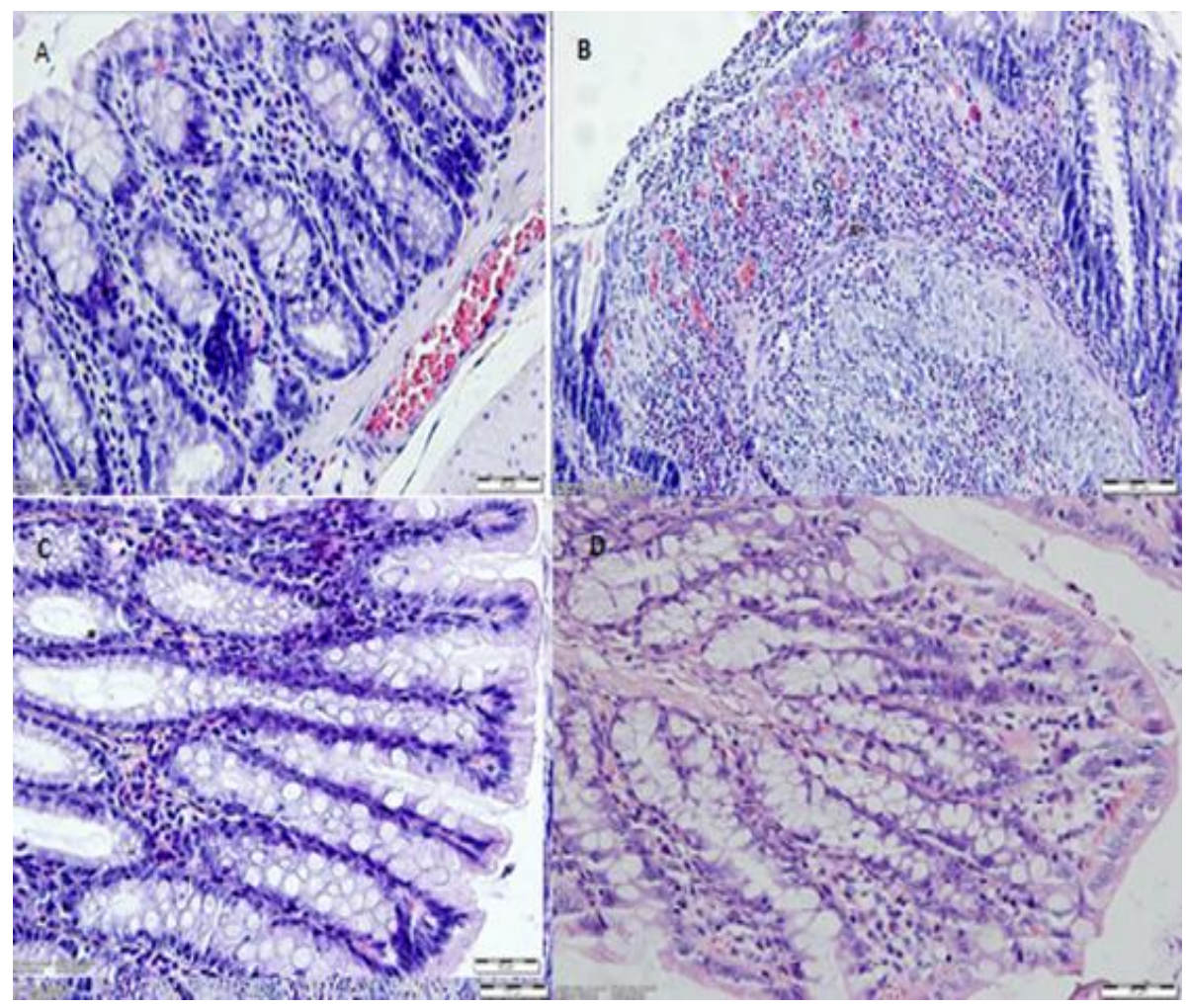

Picture-2: Histopatologic apperance of the Tissues in 40x

A:Control Group:The epithelium forming the tunica mucosa layer and the lamina propria located under the epithelium show normal alignment as required.

B: HP: The epithelium in the tunica mucosa is completely injured, in which dilate blood vessels and intense inflammatory cells are present.

C: Prednisolon: Normal image of epithelium and mucosa at close enlargement

D: Strontium: Tunica mucosa layer showing regular and close to normal viewing is being watched with close enlargement.

\section{DISCUSSION}

First of all, our study shows that oral SR is more effective than prednisolone in the treatment of colitis. However, HPE has further exacerbated inflammation.

The immune system plays an important role in the development of inflammatuary bowel diseases. Th0 cells become Th1 and Th2 with IL-12, IL-18, IL-6, TGF-B or IL-4 activation during inflammation. IFN- $\gamma$ released from Th1 cells initiates apoptosis in epithelial cells by releasing TNF $-\alpha$ from activated macrophages in the intestines.(17) SR is thought to have an effect on the immunoregulatory inflammatory cells. Recent studies have shown that IL- $1 \alpha$, IL- 6 and TNF- $\alpha$ are suppressed in vitro cell cultures (18). It has also been shown that human monocytes perform inflammatory mediator production by suppressing NF- [kappa] B activation (19). In a similar study, Firdevs $T$ et al. (7) found that that strontium chloride has comparable therapeutic efficiency with prednisolone in rat colitis model.
The anti-inflammatory effect of HPE is known. Medina et al. found that hyperphosphate contained in HP showed anti-inflammatory activity by inhibiting cyclooxygenase-1 and 5-lipoxygenase. Hyperforin was also associated with a proinflammatory response of leukocytes.(14)

We have planned this study in the light of all this information, we investigated the effect of SR and HPE on inflammation in experimental colitis and compared it with a novel therapeutic agent prednisolone. In our histopathological results, we observed that SR was effective in the cure of colitis, as in Firdevs et al. (7). On the other hand, oral application of HPE has been shown to exacerbate inflammation in the colon segments. . If it was applied topically or rectally, as it was used in burn treatment (20), it could be a healing effect, but in this study, we were not able to perform rectal application.

Finally, we concluded that SR was effective, but HPE should not be used orally.in the treatment of 
colitis. However, further studies in different phases are needed to confirm our results.

\section{REFERENCES}

1. Breese EJ, Michie CA, Nicholls SW, Murch SH, Williams CB, Domizio P, et al. Tumor necrosis factor alpha-producing cells in the intestinal mucosa of children with inflammatuary bowel disease. Gastroenterogy 1994; 106(6): 1455-66.

2. Reimund JM, Wittersheim C, Dumont S, Muller CD, Kenny JS, Baumann R, et al. Increased production of tumour necrosis factor-alpha, interleukin-1 beta, and interleukin- 6 by morphologically normal intestinal biopsies from patients with Crohn's disease. Gut 1996: 39(5): 684-9.

3. Stack WA, Mann SD, Roy AJ, Heath P, Sopwith M, Freeman J, et al. Randomised controlled trial of CDP571 antibody to tumour necrosis factor-alpha in Crohn's disease. Lancet 1997; 349 (9051): 521-4.

4. Rutgeerts P, D'Haens G, Targan S, Vasiliauskas E, Hanauer SB, Present DH, et al. Efficacy and safety of retreatment with anti-tumor necrosis factor antibody (infliximab) to maintain remission in Crohn's disease. Gastroenterology 1999;117(4):761-9.

5. Targan SR, Hanauer SB, van Deventer SJ, Mayer L, Present DH, Braakman Tet al. A short-term study of chimeric monoclonal antibody cA2 to tumor necrosis factor alpha for Crohn's disease. Crohn's Disease cA2 study Group. New England journal of Medicine 1997;337(15):1029-35.

6. Yamamoto Y, Gaynor RB. Therapeutic potential of inhibition of the NF- $\kappa$ B pathway in the treatment of inflammation and cancer. The Journal of Clinical Investigation 2001;107(2):135-142.

7. Topal, F, Yonem O, Tuzcu N, Tuzcu M, Ataseven H, Akyol M. Strontium chloride: can it be a new treatment option for ulcerative colitis? Biomed. Research International 2014; 2014: 530687.doi:10.1155/2014/530687.

8. Collaert B, Fischer C. Dentine hypersensitivity: a review Endodontics \& Dental Traumatology 1991;7: 145-152.
9. Autio KA, Scher HI, Morris HI. Therapeutic strategies for bone metastases and their clinical sequelae in prostate cancer Current Treatment Options in Oncology 2012; 13: 174-188.

10. Yamaguchi M, Weitzmann MN. The intact strontium ranelate complex stimulates osteoblastogenesis and suppresses osteoclastogenesis by antagonizing NF- $\kappa \mathrm{B}$ activation Molecular and Cellular Biochemistry 2012; 359: 399-407.

11. Buache E, Velard F, Bauden E. Effect of strontium substituted biphasic calcium phosphate on inflammatory mediators production by humanmonocytes Acta Biomateriali 2012; 8: 3113-3119.

12. Bay top T. Medical plants used in Turkey. Therapy with plants in Turkey (past and present) 2nd ed. Istanbul: Nobel Medical Bookstore; 1999: 166-7.

13. Mukherjee PK, Saritha GS, Suresh B. Antibacterial spectrum of Hypericum hookerianum. Fitoterapia 2001; 72: 55860.

14. Medina MA, Martínez-Poveda B, AmoresSánchez MI, Quesada AR. Hyperforin: more than an antidepressant bioactive compound? Life Science 2006; 79(2): 105-11.

15. K. Mousavizadeh, R. Rahimian, G. Fakhfouri, et al. Antiinflammatory effects of 5-HT receptor antagonist, tropisetron on experimental colitis in rats. European Journal of Clinical Investigation2009; 39: 375-83.

16. Chui CJ, Mc Ardle AH, Brown R, Scott HJ, Gurd FN. Intestinal mucosal lesion in low flow states. A morphological hemodynamic and metabolic reappraisal. Arch Surg 1970;101(4):478-83.

17. A. Geremia, P. Biancheri, P. Allan, G. R. Corazza, A. di Sabatino. Innate and adaptive immunity in inflammatory bowel disease Autoimmunity Reviews 2014; 13 : 3-10.

18. P. Celerier, A. Richard, P. Litoux, B. Dreno. Modulatory effects of selenium and strontium salts on keratinocytederived inflammatory cytokines Archives of Dermatological Research 1995; 287(7) 680-682, 1995. 
19. E. Buache, F. Velard, E. Bauden, Guillaume C, Jallot E, Nedelec JM, et al. Effect of strontiumsubstituted biphasic calcium phosphate on inflammatory mediators production by humanmonocytes Acta Biomaterialia 2012; 8 (8) 3113-3119.

20. Peksen ME, Kurt A, Soylu S, Tuzcu M, Bostanc1 ME, Mollaoglu MC, et al. Comparison of the healing effects of silver sulfodiazine cream $1 \%$ and the extract of Hypericum Perforatum on scald burn wound in a rat model. $2014 ; 3: 1-8$. 